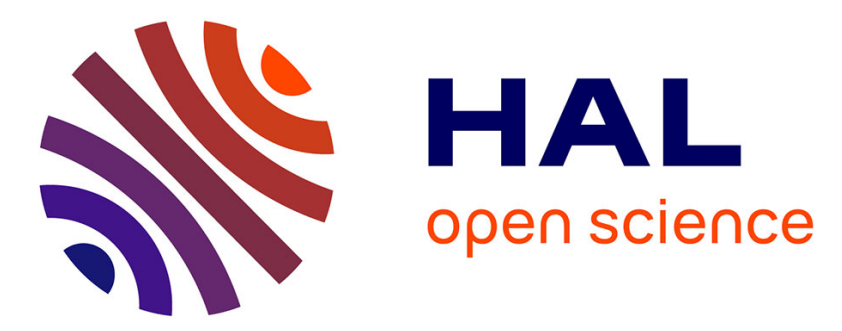

\title{
Study of potential transfer of aluminum to the brain via the olfactory pathway
}

\author{
Monique Chalansonnet, Nathalie Carabin, Stéphane Boucard, Lise Merlen, \\ Mathieu Melczer, Guillaume Antoine, Jérôme Devoy, Aurélie Rémy, François
}

Gagnaire

\section{To cite this version:}

Monique Chalansonnet, Nathalie Carabin, Stéphane Boucard, Lise Merlen, Mathieu Melczer, et al.. Study of potential transfer of aluminum to the brain via the olfactory pathway. Toxicology Letters, 2018, 283, pp.77 - 85. 10.1016/j.toxlet.2017.11.027 . hal-01845514

\section{HAL Id: hal-01845514 \\ https://hal.science/hal-01845514}

Submitted on $20 \mathrm{Jul} 2018$

HAL is a multi-disciplinary open access archive for the deposit and dissemination of scientific research documents, whether they are published or not. The documents may come from teaching and research institutions in France or abroad, or from public or private research centers.
L'archive ouverte pluridisciplinaire HAL, est destinée au dépôt et à la diffusion de documents scientifiques de niveau recherche, publiés ou non, émanant des établissements d'enseignement et de recherche français ou étrangers, des laboratoires publics ou privés.

\section{(1)(1) $\$(0)$}

Distributed under a Creative Commons Attribution - NonCommercial - ShareAlikel 4.0 


\section{Toxicology letters}

\section{Study of potential transfer of aluminum to the brain via the olfactory pathway.}

Monique Chalansonnet*, Nathalie Carabin, Stéphane Boucard, Lise Merlen, Mathieu Melczer, Guillaume Antoine, Jérôme Devoy, Aurélie Remy, François Gagnaire.

INRS, Département Toxicologie et Biométrologie, Rue du Morvan, CS 60027, F-54519 Vandœuvre-lèsNancy, France

* To whom correspondence should be addressed: monique.chalansonnet@inrs.fr; INRS, 54519 Vandœuvre-lès-Nancy, France. 


\author{
Abbreviations \\ $\mathrm{AlCl}_{3}$ : Aluminum chloride \\ $\mathrm{AlF}_{3}$ : Aluminum Fluoride \\ BPM: beats per minute \\ CNS: Central Nervous System \\ GF-AAS: Graphite Furnace Atomic Absorption Spectrometry \\ HES: Hematoxilin-Eosin-Safran \\ ICP-MS: Inductively Coupled Plasma Mass Spectrometry \\ NPs: Nanoparticles \\ OBs: Olfactory bulbs \\ PDI: Polydispersity indices \\ $\mathrm{ZnSO}_{4}$ : Zinc Sulfate
}

\title{
Highlights
}

1. Aluminum salts detected at low levels in the brain after intranasal instillation

2. Aluminas are not transferred to the brain via the olfactory pathway

3. No significant lesions in the olfactory mucosa after treatment with aluminas 


\begin{abstract}
Many employees in the aluminum industry are exposed to a range of aluminum compounds by inhalation, and the presence of ultrafine particles in the workplace has become a concern to occupational health professionals. Some metal salts and metal oxides have been shown to enter the brain through the olfactory route, bypassing the blood-brain barrier, but few studies have examined whether aluminum compounds also use this pathway. In this context, we sought to determine whether aluminum was found in rat olfactory bulbs and whether its transfer depended on physicochemical characteristics such as solubility and granulometry. Aluminum salts (chloride and fluoride) and various nanometric aluminum oxides (13 nm, $20 \mathrm{~nm}$ and $40-50 \mathrm{~nm}$ ) were administered to rats by intranasal instillation through one nostril (10 $\mu \mathrm{g} \mathrm{Al} / 30 \mu \mathrm{L}$ for 10 days). Olfactory bulbs (ipsilateral and contralateral relative to instilled nostril) were harvested and the aluminum content was determined by graphite furnace atomic absorption spectrometry after tissue mineralization. Some transfer of aluminum salts to the central nervous system via the olfactory route was observed, with the more soluble aluminum chloride being transferred at higher levels than aluminum fluoride. No cerebral translocation of any of the aluminas studied was detected.
\end{abstract}

Key words: intranasal instillation; alumina; aluminum salts; olfactory pathway; rats 


\section{Introduction}

Aluminum is widely used in a range of products from packaging to construction. Workers in this industry may be exposed to inhalation of aluminum in the workplace, and occupational health professionals are particularly concerned by exposure to fine particles.

Many external pollutants can reach the brain via the olfactory pathway whereby inhaled molecules directly in contact with the olfactory receptors in the nasal mucosa can transit along the olfactory nerve. This pathway applies not only to soluble compounds, but also to particulate or colloidal entities such as viruses, proteins or colloidal gold particles. Passage through the olfactory pathway effectively bypasses the blood-brain barrier to result in brain penetration (Barnett and Perlman, 1993; De Lorenzo, 1970; Shipley, 1985).

Many animal studies have shown that a number of soluble metal salts (manganese, cadmium, nickel, mercury, cobalt, zinc) access the central nervous system by bypassing the blood-brain barrier via the olfactory pathway (Sunderman, 2001; Tjälve and Henriksson, 1999). However, the different metals have different capacities to reach the most central brain structures. Thus, after intranasal instillation or inhalation exposure, some metals such as cadmium are concentrated in the anterior parts of the olfactory bulb but do not pass the synaptic junctions between the primary and secondary olfactory neurons (Evans and Hastings, 1992; Sun et al., 1996). In contrast, nickel is transported to the olfactory glomeruli and then slowly migrates to more central structures in the central nervous system (olfactory tubercle and the rostral parts of pre-piriform, frontal and cingulate cortex) (Henriksson et al., 1997). After intranasal instillation or exposure to an aerosol, manganese migrates rapidly along axons, accumulates in the olfactory bulb, and is then transported through secondary and tertiary olfactory pathways to reach central structures such as the olfactory cortex, hypothalamus, thalamus and the hippocampus (Brenneman et al., 2000; Dorman et al., 2001; Gianutsos et al., 1997; Tjälve et al., 1996).

Because of these observations, the olfactory pathway was also studied as a potential route of entry to the brain for insoluble ultrafine particles (Elder et al., 2006; Kao et al., 2012; Kreyling, 2016; Oberdörster et al., 2004; Tin-Tin-Win-Shwe et al., 2008; Wang et al. 2007, 2008). After intranasal instillation, electron microscopy observation showed radioactive gold particles (size $50-\mathrm{nm}$ ) to penetrate the central nervous system (De Lorenzo, 1970). These results were subsequently confirmed by several teams in several animal species. Inhalation or intranasal instillation of carbon particles also led to significant accumulation in the olfactory bulb of rats (Oberdörster et al., 2004) and altered cytokine expression patterns in the olfactory bulb (Tin-Tin-Win-Shwe et al., 2008). After intranasal instillation, insoluble ultrafine manganese oxide particles were observed to migrate in the same way as soluble manganese chloride, through the olfactory tract (Elder et al., 2006). More recent studies showed that titanium, iron and zinc oxide particles could also access the central nervous system via the olfactory pathway (Tin-Tin-Win-Shwe et al., 2008; Wang et al., 2007; Kao et al., 2012).

While the neurotoxicity of aluminum is well known (Yokel and McNamara, 2001), few studies to date have examined the potential migration of aluminum and its compounds to the central nervous system via the olfactory pathway (Divine et al., 1999; Perl et al., 1987; Zatta et al., 1993). Most of these previous studies used salts such as acetylacetonate, lactate and aluminum chloride. Through powerful techniques to detect and visualize aluminum on sections of olfactory bulbs (OBs) (fluorescence, LAMMA laser microprobe analysis), these studies showed that soluble aluminum compounds could also reach the olfactory bulb by axonal transport from the olfactory epithelium (Divine et al., 1999; Perl et al., 1987; Zatta et al., 1993). However, the potential significance of this route has yet to be quantified. In recent years, a number of studies sought to determine the brain toxicity of alumina nanoparticles after oral and inhalation exposure (Prabhakar et al., 2012; Zhang et al., 2011), but few have explored how insoluble alumina particles are transported to the brain by the olfactory pathway after intranasal instillation in rats (Kwon et al., 2013) or via a respiratory route (Zhang et al., 2015). Kwon et al. (2013) showed an increase in aluminum content in the olfactory bulb, as quantified by inductively coupled plasma mass spectrometry (ICP-MS) with a relatively high 
dose of aluminum nanoparticles (Al-NPs) ( $40 \mathrm{mg} / \mathrm{kg}$ body weight) and concluded that Al-NPs could penetrate the brain through the olfactory pathway.

The aim of the study described here was to investigate the potential transfer of aluminum toward the brain, and particularly the OBs, via the olfactory pathway taking parameters such as solubility and granulometry of the aluminum compounds into account. Various aluminum compounds (aluminum chloride, aluminum fluoride and three aluminas) were administered to rats by intranasal instillation for ten days. Aluminum concentrations were then measured in brain tissues by Graphite Furnace Atomic Absorption Spectroscopy (GF-AAS).

Following each treatment, the olfactory epithelium was morphologically assessed.

\section{Methods}

\subsection{Chemicals}

Aluminum chloride ( $\geq 99 \%)\left(\mathrm{AlCl}_{3}, 6 \mathrm{H}_{2} \mathrm{O}\right)$ was purchased from Fluka (Buchs, Switzerland), aluminum fluoride (99.999\%) $\left(\mathrm{AlF}_{3}, \mathrm{H}_{2} \mathrm{O}\right)$ and zinc sulfate heptahydrate were purchased from Acros (Geel, Belgium).

13-nm aluminum oxide and manganese chloride $\left(\mathrm{MnCl}_{2}, 4 \mathrm{H}_{2} \mathrm{O}\right)$ were purchased from Sigma-Aldrich (France). 40-50-nm and 20-nm aluminum oxide were purchased from Alfa Aesar (Emmerich am Rhein, Germany).

\subsection{Animals}

Rats were randomly assigned to control and exposed groups. Before the study period, male Sprague Dawley rats (Charles River, Saint-Germain-sur-l'Arbresle, France), weighing 250-275 g, were housed for 7 days in polycarbonate cages ( $43 \mathrm{~cm}$ long, $43 \mathrm{~cm}$ wide, $19 \mathrm{~cm}$ high, each holding six rats), on hardwood-chip bedding, under controlled environmental conditions. Room temperature $\left(22{ }^{\circ} \mathrm{C}\right)$, humidity $(55 \pm 5 \%)$ and light cycle (07:00-19:00 h) were automatically controlled. Filtered tap water (pore size $0.3 \mu \mathrm{m}$ ) and $\gamma$-ray-sterilized food (UAR-Alimentation, Epinay-sur-Orge, France) were available ad libitum. The animal facilities have full accreditation (D54-547-10), and the research described in this article was performed in line with the guide for care and use of laboratory animals promulgated by the European Parliament and Council (Directive 2010/63/EC, 2010/63/EU, 22 September 2010). The present study was approved by the institute's Scientific Advisory Board.

\subsection{Experimental paradigm}

We first validated our experimental protocol as some parameters of the intranasal instillation, such as the volume to be instilled, the depth of anesthesia or the animal's position during instillation could influence how the compound administered distributes in the nasal cavity (Southam et al., 2002).

\subsubsection{Validation of volume and route of administration}

Aluminum salts were administered to anesthetized rats (as described in paragraph 2.3.5) by intranasal instillation in the left nostril. No instillation was performed on the right side, which was used for comparison. Control rats received equal volumes of saline instilled into the left nostril. To ensure that the volume administered was sufficient to reach the olfactory mucosa while being small enough not to cross over to the opposite side through the septal window, a range of volumes $(30,50$ and $100 \mu \mathrm{L})$ of $5 \%$ Zinc Sulfate $\left(\mathrm{ZnSO}_{4}\right)$ solution was administered to rats by intranasal instillation. Rats were euthanized 72 hours after treatment. This reference compound is known to induce necrosis in olfactory mucosa (Ducray et al., 2002; Hansen et al., 1994). The extent of the effect of $\mathrm{ZnSO}_{4}$ was examined by histological analysis.

The relevance of the mode of administration (intranasal instillations) of aluminum compounds was tested on groups of eight rats, each instilled in the same conditions with manganese chloride, a salt known to reach the brain via the olfactory pathway. Manganese metal $(\mathrm{Mn})(10 \mu \mathrm{g}$ and $25 \mu \mathrm{g}$ in a 30$\mu \mathrm{L}$ volume of sterile saline) was instilled as a single dose, or repeated instillations of $10 \mu \mathrm{g} \mathrm{Mn} / 30 \mu \mathrm{L}$ 
in the same vehicle were performed over 10 days. Rats were euthanized $24 \mathrm{~h}$ after administering the compound. The 24-h interval was chosen since previous results indicated that this time period is sufficient for $\mathrm{Mn}$ to be transported in adequate amounts along the olfactory pathway to the brain (Gianutsos et al., 1997). Manganese levels were determined in olfactory bulbs (OBs) by GF-AAS. The tissue manganese concentration was sufficient to use a single olfactory bulb for each assay. Eight control rats and eight treated rats were used in this experiment.

\subsubsection{Validation of tissue aluminum assay method}

Preliminary tests with aluminum salts $\left(\mathrm{AlCl}_{3}, \mathrm{AlF}_{3}\right)$ revealed that the analytical method was insufficiently sensitive to determine aluminum levels in a single olfactory bulb. Therefore, for each assay eight OBs had to be pooled to be above the limit of quantification for the assay. The analytical method's (AAS) sensitivity to variations in tissue aluminum concentrations after exposure to aluminum was verified after intraperitoneal administration of aluminum chloride, as increases in brain aluminum levels have been reported in the literature after exposure via this route (SánchezIglesias et al., 2007). Animals were treated for 7 days with $10 \mathrm{mg}$ of aluminum metal $/ \mathrm{kg}$. Control animals received saline. Aluminum levels were determined in OBs collected $24 \mathrm{~h}$ after the last day of treatment (eight bulbs per assay $=4$ rats, six assays i.e., 24 rats) and the cerebellum (1 cerebellum per assay $=24$ assays).

\subsubsection{Doses and preparation of aluminum compounds}

For each compound, the equivalent $\mathrm{Al}$ metal $10-\mu \mathrm{g}$ dose was selected. $\mathrm{AlCl}_{3}$ is fully watersoluble and $\mathrm{AlF}_{3}$ is soluble in water at $0.5 \mathrm{~g} / 100 \mathrm{~mL}$.

Aluminum salt solutions and alumina suspensions were prepared daily. Aluminum salts were dissolved in sterile saline. Osmolarity of the suspensions and solutions instilled was checked with an osmometer (Vapro osmometer 5520). The $\mathrm{pH}$ of the aluminum fluoride suspension was adjusted to 7.0 with $\mathrm{NaOH} 10 \mathrm{~N}$.

Alumina powders were suspended in sterile saline $0.9 \%$ and ultrasonicated for 16 min on ice using a Bransonic sonifier 450 (Branson Ultrasonics Corp., Danbury, Connecticut, USA) set at $10 \%$ amplitude. Suspensions were administered to the rats at room temperature and were vortexed for 30 seconds before each instillation. Preliminary experiments were performed to check the homogeneity of the alumina suspensions over time and to ensure that the same concentration of aluminum was delivered to each rat.

\subsubsection{Characterization of Al-NPs}

A thorough characterization of NPs was conducted using a panel of complementary techniques. Primary particle size was determined by transmission electron microscopy (TEM). Particle powders suspended in isopropanol were loaded onto TEM grids under vacuum and observed with a $120 \mathrm{kV}$ Zeiss EM 910 TEM (Zeiss, Germany). The specific surface area (SSA) of the nanopowder was determined by the Brunauer-Emmett-Teller (BET) method. The degree of crystallinity of all samples was determined by X-Ray Diffraction (XRD) using an X'PERT diffractometer (Panalytical, the Netherlands). Concentrations of major impurities were determined by inductively coupled plasma and atomic emission spectrometry (ICP-AES). The state of dispersion of Al-NPs in saline was analyzed by dynamic light scattering (DLS) with a VASCO-2 particle-size analyzer (Cordouan Technologies, France).

\subsubsection{Intranasal instillation protocol and tissue sampling}

Solutions and suspensions were instilled intranasally into the left nostril (ipsilateral side) of 8-weekold male Sprague Dawley rats (300-325 g) were premedicated with levomepromazine $(5 \mathrm{mg} / \mathrm{kg}$, i.p.) before anesthesia with ketamine $(100 \mathrm{mg} / \mathrm{kg}$, i.m.). Aluminum salts were slowly instilled into the 
nostrils of the rats in supine position. Rats were kept in this position until they woke from anesthesia. For each compound, $30 \mu \mathrm{L}$ was administered into the nostril. Repeated instillations were performed as follows: two days of instillation followed by two days without treatment on week 1, five days of instillation followed by two days without treatment on week 2 and three days of instillation on week 3. Twenty-four hours after the final instillation, rats were deeply anesthetized with pentobarbital 60 $\mathrm{mg} / \mathrm{kg}$ ) and exsanguinated through the abdominal aorta. To measure plasma aluminum levels, blood samples were collected in heparinized polypropylene tubes. After centrifugation at $3000 \mathrm{~g}$, plasma was placed in a fresh tube before storage in liquid nitrogen prior to determination of aluminum levels by GF-AAS. The ipsilateral and contralateral OBs were collected and placed in polypropylene tubes previously washed with an aqueous solution of $10 \%$ nitric acid. When harvesting tissues, between animals, surgical instruments (scissors, scalpels and surgical clips) were rinsed with a $10 \%$ nitric acid solution followed by ultrapure water.

\subsection{Aluminum assay}

Eight OBs were pooled for each assay. For each compound, 8 to 9 assays were performed on ipsilateral and contralateral OBs collected from control and treated rats.

As aluminum is a ubiquitous element, great care was taken at all stages of preparation to avoid sample contamination. All the materials used in assays (plastic flasks, reactors, injection cups, micropipette tips) were rinsed with ultrapure nitric acid (Plasma-Pur, SCP Science) followed by ultrapure water to reduce residual aluminum contamination. The OBs ( 8 for each assay) were placed in reactors with $0.25 \mathrm{~mL}$ hydrogen peroxide, $0.75 \mathrm{~mL}$ nitric acid (Plasma-Pur plus 67-69 \%) and 0.75 $\mathrm{mL}$ ultrapure water. Tissues were mineralized at $200 \mathrm{C}$ in a digester microwave (Mars Xpress). For each tissue mineralization series, blanks containing only the reagents (without tissue) were added to the reactors to check for assay contamination.

Aluminum in $\mathrm{OBs}$ was quantified using a Zeeman atomic absorption spectrophotometer (Varian SpectrAA-220Z). A titration curve (0 to $2 \mu \mathrm{g} / \mathrm{L}$ ) was established from stock solutions in $5 \%$ nitric acid. A matrix modifier, ammonium dichromate $(6 \mu \mathrm{L})$ was added to the sample at the time of injection into the graphite tube. Samples were concentrated by performing four successive sample injections, only the last of which underwent the entire electrothermal program. Tissue aluminum levels were expressed in $\mu \mathrm{g} / \mathrm{g}$ of fresh tissue.

\subsection{Histopathological examination}

Nasal mucosa from groups of 3 to 5 additional rats for each of the aluminum compounds studied were histologically examined. Nasal mucosa were carefully dissected according to the protocol described in Gagnaire and Boucard (2015). Briefly, rats were anesthetized with sodium pentobarbital $(10 \mathrm{mg} / \mathrm{mL} ; 1 \mathrm{~mL})$ and perfused via the left ventricle with $0.1 \mathrm{M}$ phosphate-buffered saline (PBS) containing sodium heparin ( 10 units $/ \mathrm{mL}, \mathrm{pH}=7.4$ ), followed by Bouin's solution. Fixative solution was also flushed through the trachea to fill the nasal cavity. Skulls were collected and decalcified in a solution containing 17\% disodium ethylenediaminetetraacetate, $\mathrm{pH}=7.4$ (Osteosoft, Merck, Darmstadt, Germany) and 4\% formaldehyde. Transversal tissue blocks were cut according to Young (1981), through levels: (I) immediately posterior to the upper incisive tooth; (II) through the incisive papilla; (III) through the second palatal ridge, and; (IV) in the middle of the first upper molar teeth (Fig. 1). Tissue blocks were dehydrated in graded alcohol solutions and embedded in paraffin. Sections ( $3.5 \mu \mathrm{m}$ thick) were mounted on Superfrost Plus slides and stained with hematoxilin-eosinsafran (HES) for routine histology.

Insert Figure 1 about here

\subsection{Statistical analysis}

For each compound, 8 to 9 assays were carried out on ipsilateral and contralateral bulbs from control and treated rats. 
A log transformation was applied to normalize data. The homogeneity of variances was checked by the Bartlett's test. Statistical analyses were performed using Statgraphics Centurion XVI. All data are presented as mean \pm SEM. For all analyses, the significance threshold was set at $p<0.05$. An independent samples $t$ test was used to compare aluminum concentrations in the ipsilateral bulbs of treated and control rats. A paired Student's $t$ test was used to compare aluminum concentrations in ipsilateral and contralateral bulbs from treated rats.

\section{Results}

\subsection{Validation of the volume for intranasal instillation}

$30 \mu \mathrm{L}$ of $\mathrm{ZnSO}_{4}$ generated lesions at all levels of the olfactory mucosa (II-III and IV) only on the instilled side (Fig.2). The $50 \mu \mathrm{L}$ volume was associated with slight inflammation in the opposite nostril, potentially due to penetration of $\mathrm{ZnSO}_{4}$ through the septal window as described in the literature (Brenneman et al., 2000; Hansen et al., 1994). The $100 \mu \mathrm{L}$ volume caused extensive lesions on both sides. Based on these results, $30 \mu \mathrm{L}$ was selected as the volume to be used in further experiments.

\subsection{Validation of the intranasal instillation method}

\section{Insert Figure 2 about here}

The limits of detection and quantification for manganese by AAS were 36 and $130 \mathrm{ng} / \mathrm{g}$ of fresh tissue, respectively.

Single instillations of $10 \mu \mathrm{g}$ and $25 \mu \mathrm{g}$ of $\mathrm{Mn}$ metal and repeated instillations of $10 \mu \mathrm{g} \mathrm{Mn}$ resulted in very significant increases in the manganese concentrations in the ipsilateral bulbs (Fig.3). After a single instillation of $10 \mu \mathrm{g} \mathrm{Mn}$, the manganese concentration in ipsilateral bulbs was $329 \%$ of that measured in contralateral bulbs $(p<0.001)$. When $25 \mu \mathrm{g} \mathrm{Mn}$ was instilled, the difference was 395\%. Repeated instillations of $10 \mu \mathrm{g} \mathrm{Mn} \mathrm{(10} \mathrm{days)} \mathrm{also} \mathrm{caused} \mathrm{a} \mathrm{395 \%} \mathrm{increase} \mathrm{in} \mathrm{manganese}$ concentrations in ipsilateral bulbs compared to contralateral bulbs. In addition, manganese concentrations in contralateral bulbs from treated rats were $72.7 \%$ higher than those observed in contralateral bulbs from control rats $(p<0.001)$. This slight increase in manganese concentrations in contralateral OBs from treated rats prompted us to maintain a control group for each experiment to allow comparison of the aluminum concentrations in the ipsilateral bulbs from treated animals to concentrations measured in the ipsilateral bulbs from control animals.

Insert Figure 3 about here

\subsection{Validation of the method used to determine tissue aluminum levels}

The limits of detection and quantification of aluminum in OBs by the AAS method were, respectively, 6 and $18 \mathrm{ng} / \mathrm{g}$ of fresh tissue. Tissue aluminum levels in the OBs of control rats were around $\mathbf{0 . 0 3}$ $\mu \mathrm{g} / \mathrm{g}$ of fresh tissue.

Intraperitoneal treatment with $\mathrm{AlCl}_{3}(10 \mathrm{mg} \mathrm{Al}$ metal $/ \mathrm{Kg}$ ) caused significant increases in aluminum levels in the OBs and cerebellum, of $210 \%$ and $367 \%$, respectively $(p<0.001)$ (Fig.4A). A significant ( $p$ $<0.001$ ) increase in plasma concentration was also observed between control and treated rats (Fig 4B). Thus, plasma aluminum concentrations in control rats were $2.3 \mu \mathrm{g} / \mathrm{L}$, as compared to $384 \mu \mathrm{g} / \mathrm{L}$ in treated rats

Insert Figure 4 about here

\subsection{Aluminum chloride instillations}

\subsubsection{Histopathology}

No treatment-related lesions were observed in the olfactory mucosa of rats exposed to $\mathrm{AlCl}_{3}$ at $10 \mu \mathrm{g}$ $\mathrm{Al} / 30 \mu \mathrm{L}$ for ten days (Fig. 5). 


\subsubsection{Aluminum concentrations in $\mathrm{OBs}$}

The mean aluminum concentrations in control rat OBs was around $0.03 \mu \mathrm{g} / \mathrm{g}$ (Fig. 6). Aluminum chloride instillations caused a $123 \%$ increase in aluminum levels in the ipsilateral OBs compared to control animals $(p<0.001)$. There was a significant $(53 \%)$ increase in aluminum concentration between ipsilateral OBs and contralateral OBs from treated rats $(p=0.02)$. Moreover, the aluminum concentrations determined for contralateral bulbs from treated rats were higher than those determined for control rats $(p=0.03)$.

No significant difference in plasma concentrations was found between control and treated rats (data not shown).

Insert Figure 6 about here

\subsection{Aluminum fluoride instillations}

\subsubsection{Histopathology}

Instillation of aluminum fluoride at $10 \mu \mathrm{g} \mathrm{Al} / 30 \mu \mathrm{L}$ over 10 days resulted in limited lesions of the olfactory epithelium in the instilled nostril. Lesions were only observed in the most posterior part of the nasal passages at level IV, in the inner folds of ethmoid turbinates I and II, in two out of three animals exposed to aluminum fluoride (Fig.7A). Although limited in extent, the lesions observed were severe, with loss of cells from the epithelium to the basal cell layer, and exfoliation of the epithelium in the meatus (Fig.7B). No histological lesions of the respiratory, transitional or stratified squamous mucosal portions of the nasal tissues were observed.

\subsubsection{Aluminum concentrations in $\mathrm{OBs}$}

\section{Insert Figure 7 about here}

A $63 \%$ increase in the aluminum concentrations in the ipsilateral OBs of treated rats compared to control rats was observed $(p=0.029)$. In treated rats, the difference between aluminum concentrations in ipsilateral OBs and contralateral OBs was not significant.

A trend for increased aluminum concentrations in contralateral bulbs from treated rats compared to control rats was observed, but it was not significant.

\section{Insert Figure 8 about here}

\subsection{Aluminum oxide instillations}

\subsubsection{Particle characterization}




\begin{tabular}{|c|c|c|c|c|c|c|}
\hline \multirow{2}{*}{$\begin{array}{l}\text { Supplier } \\
\text { data }\end{array}$} & \multirow{2}{*}{$\begin{array}{l}\text { Particle size } \\
\text { (TEM) }\end{array}$} & \multirow{2}{*}{$\begin{array}{l}\text { BET SSA } \\
\left(\mathrm{m}^{2} \mathrm{~g}^{-1}\right)\end{array}$} & \multicolumn{2}{|c|}{ DLS } & \multirow{2}{*}{$\begin{array}{l}\text { Chemical } \\
\text { purity (\%) }\end{array}$} & \multirow{2}{*}{$\begin{array}{l}\text { Major } \\
\text { crystalline } \\
\text { forms }\end{array}$} \\
\hline & & & $\begin{array}{l}\text { Dmean } \\
\text { intensity }\end{array}$ & PDI & & \\
\hline $\begin{array}{c}\mathrm{Al}_{2} \mathrm{O}_{3} \\
\text { Sigma- } \\
\text { Aldrich } \\
13 \mathrm{~nm}\end{array}$ & $14 \pm 3 \mathrm{~nm}$ & $96 \mathrm{~m}^{2} / \mathrm{g}$ & 732.80 & 0.0260 & $93 \%$ & $\begin{array}{c}\mathrm{Y}-\mathrm{Al}_{2} \mathrm{O}_{3}+\delta- \\
\mathrm{Al}_{2} \mathrm{O}_{3}\end{array}$ \\
\hline $\begin{array}{c}\mathrm{Al}_{2} \mathrm{O}_{3} \\
\text { Alfa Aesar } \\
20 \mathrm{~nm}\end{array}$ & $\begin{array}{l}\text { Not measured } \\
\text { reliably }\end{array}$ & $219 \mathrm{~m}^{2} / \mathrm{g}$ & 1258.20 & 0.0480 & $93 \%$ & $\mathrm{~V}-\mathrm{Al}_{2} \mathrm{O}_{3}$ \\
\hline $\begin{array}{c}\mathrm{Al}_{2} \mathrm{O}_{3} \\
\text { Alfa Aesar } \\
40-50 \mathrm{~nm}\end{array}$ & $37 \pm 17 \mathrm{~nm}$ & $37 \mathrm{~m}^{2} / \mathrm{g}$ & 167.07 & 0.1120 & $98.8 \%$ & $\begin{array}{c}\mathrm{Y}-\mathrm{Al}_{2} \mathrm{O}_{3}+\delta- \\
\mathrm{Al}_{2} \mathrm{O}_{3}\end{array}$ \\
\hline
\end{tabular}

Table 1. Chemical and physical particle characterization. PDI: Polydispersity indices

The supplier's data concerning the particle size for $\mathrm{Al}_{2} \mathrm{O}_{3} 20 \mathrm{~nm}$ did not correspond to our observations made by TEM. Although not very reliable, the TEM measurements of $20 \mathrm{~nm}$ alumina with the equipment available in our laboratory (Zeiss model EM910) indicated that the primary particles had rather an average diameter close to $5 \mathrm{~nm}$. Moreover, an estimate of the particle size by applying the formula:

$$
d_{p}\left(\text { or } d_{B E T}\right)=\frac{6}{S S A_{B E T} x d \mathrm{Al}_{2} \mathrm{O}_{3}}
$$

dp: particle diameter (in $\mu \mathrm{m}$ ); SSA: specific surface area (in $\mathrm{m} 2 \mathrm{~g}-1$ ), $\mathrm{d}$ : density of Al2O3 particle = 3.97.

Application of this formula indicated a dBET of around $6 \mathrm{~nm}$, in agreement with our TEM data.

\subsubsection{Histopathology}

None of the treatments with the different aluminas caused lesions in the olfactory mucosa (data not shown).

\subsubsection{Aluminum concentrations in $\mathrm{OBs}$}

With the aluminas studied, no variations in aluminum concentrations were found between treated ipsilateral OBs and control ipsilateral OBs, nor between treated ipsilateral OBs and contralateral OBs from treated rats (data not shown).

\section{Discussion}

In this study, we investigated whether aluminum compounds could reach the central nervous system via the olfactory nerve. Our study protocol involved intranasal instillation of various aluminumcontaining compounds, in either soluble or particulate form. Before studying the possible passage of various aluminum compounds to the central nervous system via the olfactory pathway, we validated our experimental model. First, with the help of a solution of zinc sulfate, we found that a $30-\mu \mathrm{L}$ volume allowed the instilled compound to distribute to all levels of the olfactory mucosa, on the instilled side only. Secondly, in our experimental conditions (intranasal instillation of $30 \mu \mathrm{L}$ in anesthetized animals lying on their backs), the instillation of a solution of manganese chloride highlighted transfer of manganese to the central nervous system via the olfactory pathway, as previously reported (Elder et al., 2006; Gianutsos et al., 1997). The slight increase in manganese concentrations in contralateral OBs from treated rats might be explained by systemic distribution which is possible with the 10-day instillation protocol, as indicated previously (Brenneman et al., 
2000). Finally, the aluminum assay used in our laboratory was sensitive enough to show significant increases in aluminum concentrations in the $\mathrm{OBs}$ and cerebellum of rats intraperitoneally administered with aluminum chloride over 7 days, in line with previous reports (Sánchez-Iglesias et al., 2007).

In this study, the mode of repeated instillations over a period of 10 days was chosen because some metals migrate very slowly through the olfactory pathways (Henriksson et al., 1997) and repeated exposure or a longer post-exposure period prior to analysis may be required for those metals to accumulate in the olfactory bulbs.

In our study, aluminum brain concentrations were quite low, at around $0.03 \mu \mathrm{g} / \mathrm{g}$, similar to those reported elsewhere (Van Ginkel et al., 1990). In order to provide reliable results, above the limit of quantification for the method ( $18 \mathrm{ng} / \mathrm{g}$ of tissue), we had to pool eight OBs for each assay. In the literature, large variations in aluminum concentrations have been reported in brains using a range of techniques, mainly graphite furnace atomic absorption spectrometry, electrothermal atomic absorption spectrometry and inductively coupled plasma mass spectrometry. Concentrations range from $0.007 \mu \mathrm{g} / \mathrm{g}$ tissue (Gómez et al., 1997) to $20 \mu \mathrm{g} / \mathrm{g}$ tissue (Abubakar et al., 2004). Because aluminum is ubiquitous, contamination from other sources may occur during tissue sampling or assays and partly explain variations between studies.

After repeated instillations of aluminum salts, significant increases in aluminum levels were observed in the ipsilateral OBs from exposed rats. The increase was more pronounced with aluminum chloride than with aluminum fluoride, possibly due to the difference in solubility between the two compounds. An influence of solubility on the passage to the OBs via the olfactory pathway has been noted with other metal salts. For example, inhalation exposure to soluble manganese sulfate resulted in higher olfactory bulb manganese concentrations than those achieved following exposure to manganese phosphate, a relatively insoluble form of manganese (Dorman et al. 2001). Nevertheless, passage of aluminum salts was low compared to that of manganese chloride. Indeed, the increase in metal concentrations between ipsilateral and contralateral OBs from treated rats was $395 \%$ with manganese chloride, $53 \%$ with aluminum chloride and $26 \%$ with aluminum fluoride. Very limited histological lesions were observed in the epithelium of only two ethmoid turbinates, there is therefore no reason to suspect that aluminum translocation in the olfactory system was significantly affected by cellular toxicity. As previously mentioned for manganese, we cannot exclude some degree of systemic passage in the 10-day exposure condition. Systemic passage could explain the slight increase in aluminum concentrations observed in contralateral OBs from treated rats, even though no differences in plasma aluminum concentrations were detected between control and treated rats. The alternative, that some of the aluminum solution administered passed through the septal window, is unlikely based on the results of the validation step where $30 \mu \mathrm{L}$ of zinc sulfate solution caused no damage to the olfactory epithelium of the contralateral nasal cavity.

Few studies have examined translocation of aluminum along the olfactory nerve into the olfactory bulb. It is therefore difficult to compare our results with those obtained in other studies. In addition, the few studies available used very different aluminum compounds (acetylacetonate, lactate and aluminum chlorohydrate), animals, modes of exposure and analytical methods to determine aluminum concentrations in brain tissues. For example, in one study, Gelfoam ${ }^{\circledR}$ saturated with a mixture of aluminum chloride and aluminum lactate was implanted in the nasal recess of rabbits for one month. This treatment induced Al-containing granulomas in the OBs. Aluminum in granulomas was not quantified, rather it was detected by laser microprobe mass spectrometry (Perl and Good, 1987). Another study demonstrated the presence of aluminum using fluorescence imaging on histological sections of brain tissues from rats exposed to an aerosol of aluminum acetylacetonate (Zatta et al., 1993). In a third study where rats were exposed to aluminum chlorohydrate via the nose only, increased aluminum levels were observed in the OBs (Divine et al., 1999). However, it is difficult to compare our results to those obtained by these authors because tissue concentrations were determined by the $\mu$-PIXE technique (micro Particle-Induced X-ray Emission).

Our results do not show aluminum transfer to OBs after repeated instillations of aluminas from a number of sources. These negative results may be due to the fact that the agglomerates generated 
during preparation of the saline suspensions cannot be transported by the olfactory fibers, which have a diameter of around 100-300 nm (Perge et al., 2012). Nevertheless, some authors have reported accumulation of gold nano-agglomerates in the brain, mainly in OBs, after inhalation exposure (Balasubramanian et al., 2013). These authors suggest that inhaled nanoparticle agglomerates may disaggregate into discrete primary nanoparticles upon contact with the olfactory mucosa. The mechanisms involved in this hypothetical disaggregation remain to be explored.

Our results are at odds with those of Kwon et al. (2013) who showed that Al-NPs accumulated in OBs and brains following nasal exposure, and could induce neurotoxicity. In their study, they exposed anesthetized rats to $1 \mathrm{mg} / \mathrm{kg}$ body weight (low dose group), $20 \mathrm{mg} / \mathrm{kg}$ body weight (middle exposure group) or $40 \mathrm{mg} / \mathrm{kg}$ body weight (high exposure group) by intranasal instillation three times in one week with an interval of one day. These doses were much higher than those used in the study described here $(10 \mu \mathrm{g} / 30 \mu \mathrm{L}$ per day for 10 days, i.e., a total dose of $330 \mu \mathrm{g} / \mathrm{kg}$ body weight). Kwon et al. (2013) showed that the aluminum content in OBs was dose-dependent, with an approximately $175 \%$ increase in aluminum burden in OBs at the higher dose $(40 \mathrm{mg} / \mathrm{kg})$ and only a slight increase in aluminum concentration in OBs from rats exposed to the lowest dose $(1 \mathrm{mg} / \mathrm{kg}$ body weight for 3 days). This lowest dose is about three times higher than the dose used in the study described here. We also performed an experiment with 13-nm alumina at an equivalent Al metal dose of $65.3 \mu \mathrm{g}$. This dose corresponds to approximately the amount of aluminum metal that a 300 -gram rat would inhale when exposed to the (ACGIH) TLV for $\mathrm{Al}_{2} \mathrm{O}_{3}\left(1 \mathrm{mg} \mathrm{Al} / \mathrm{m}^{3}\right)$ over an 8-hour period (respiratory rate $=85 \mathrm{bpm}$, tidal volume $=1.6 \mathrm{~mL}$ ). Even at this dose, we observed no increase in aluminum concentrations in the ipsilateral bulbs of exposed rats (total dose over 10 days of treatment equivalent to $2.2 \mathrm{mg} / \mathrm{kg}$ body weight). This dose is quite similar to the lowest dose used by Kwon et al. (2013) (total dose over 3 days of treatment equivalent to $3 \mathrm{mg} / \mathrm{kg}$ body weight) which led to a slight increase in concentrations in OBs. A further difficulty in comparing our results to those obtained by Kwon et al. is due to how their results are expressed, as percentage variations compared to values for control animals. Thus, it is difficult to determine the baseline aluminum levels measured in control rats.

The results of this study raise a number of questions, in particular the relevance of the mode of exposure (instillations versus inhalation) and the doses administered as well as whether the results from model animals can be extrapolated to humans. Intranasal instillation is an inexpensive and convenient mode of exposure that allows delivery of a known amount of test material. Instillation avoids deposition in the lungs and/or on the fur which can occur with nose-only or whole-body inhalation exposure. Instillation has been used in several other studies to demonstrate the translocation of soluble or particulate materials in rodents (Evans and Hastings, 1992; Gianutsos et al., 1997; Henriksson et al., 1997; Ibanez et al., 2014; Tjälve et al., 1996). A lack of sensitivity of the animal model used in the present study (intranasal instillations in the rat) to explain the negative results obtained with alumina, is unlikely. Rats are recognized as a sensitive model for the study of the olfactory translocation of metals because the olfactory mucosa represents $50 \%$ of the nasal mucosa (in humans it represents only 5\%) (Kimbell et al., 1997). This large percentage of olfactory epithelium in the nasal cavity should favor the transport of olfactory nanoparticles into the central nervous system. One sensitive point is whether the doses administered by this means can be extrapolated to the received dose upon exposure to a given nanoparticle aerosol. Indeed, with other parameters, the size of the particles influences the efficiency of deposition and how deposited particles spatially distribute in the rat's nasal cavity (Gerde et al., 1991; Guilherme et al., 2009). For example, at a flow rate of $400 \mathrm{~mL} / \mathrm{min}$, deposition efficiency increased from 6 to $58 \%$ when the particle diameter decreased from 0.1 to 0.005 microns (Gerde et al., 1991). In the present study, it can be roughly estimated that the dose received at each instillation $(10 \mu \mathrm{g} \mathrm{Al})$ corresponds to approximately the same amount of Al that would have deposited in the nasal cavities of rats exposed for 8 hours to between 0.2 and $1 \mathrm{mg} \mathrm{Al} / \mathrm{m}^{3}$, assuming a deposition efficiency of $10 \%$ to $50 \%$. These concentrations should be compared to those detected in workplaces (aluminum foundries, welding). The literature reports very variable concentrations, depending on the industrial processes monitored, with median total aluminum levels of 0.03 to $0.084 \mathrm{mg} / \mathrm{m}^{3}$ reported for potrooms in a 
modern aluminium smelter (Röllin et al, 2001), and exposures ranging from 0.036 to $1.47 \mathrm{mg} / \mathrm{m}^{3}$ in a plant using a more traditional potroom smelting approach (Röllin et al., 1996).

In conclusion, this study reveals low-level passage of aluminum salts to the central nervous system via the olfactory pathway. The passage of aluminum chloride, the most soluble salt, was more extensive than that of aluminum fluoride. In contrast, our results show no cerebral translocation of alumina nanoparticles to the OBs via the olfactory pathways.

\section{Conflict of interest}

The authors declare no competing interests.

\section{Acknowledgements}

The authors gratefully acknowledge Marie-Josèphe Décret and Lionel Dussoul for animal care and husbandry.

\section{References}

Abubakar, M.G., Taylor, A., Ferns, G.A., 2004. Regional accumulation of aluminium in the rat brain is affected by dietary vitamin $E$. Journal of trace elements in medicine and biology : organ of the Society for Minerals and Trace Elements (GMS) 18, 53-59.

Balasubramanian, S.K., Poh, K.W., Ong, C.N., Kreyling, W.G., Ong, W.Y., Yu, L.E., 2013. The effect of primary particle size on biodistribution of inhaled gold nano-agglomerates. Biomaterials 34, 54395452.

Barnett, E.M., Perlman, S., 1993. The olfactory nerve and not the trigeminal nerve is the major site of CNS entry for mouse hepatitis virus, strain JHM. Virology 194, 185-191.

Brenneman, K.A., Wong, B.A., Buccellato, M.A., Costa, E.R., Gross, E.A., Dorman, D.C., 2000. Direct olfactory transport of inhaled manganese $((54) \mathrm{MnCl}(2))$ to the rat brain: toxicokinetic investigations in a unilateral nasal occlusion model. Toxicol. Appl. Pharmacol. 169, 238-248.

De Lorenzo, A.J.D., 1970. The olfactory neuron and the blood-brain barrier. In: Taste and smell in vertebrates . Eds : Wolstenholme G.E., and Knight J., London, Churchill, 151-176.

Divine, K.K., Lewis, J.L., Grant, P.G., Bench, G., 1999. Quantitative particle-induced X-ray emission imaging of rat olfactory epithelium applied to the permeability of rat epithelium to inhaled aluminum. Chemical research in toxicology 12, 575-581.

Dorman, D.C., Struve, M.F., James, R.A., Marshall, M.W., Parkinson, C.U., Wong, B.A., 2001. Influence of particle solubility on the delivery of inhaled manganese to the rat brain: manganese sulfate and manganese tetroxide pharmacokinetics following repeated (14-day) exposure. Toxicology and applied pharmacology 170, 79-87.

Ducray, A., Bondier, J.R., Michel, G., Bon, K., Millot, J.L., Propper, A., Kastner, A., 2002. Recovery following peripheral destruction of olfactory neurons in young and adult mice. The European journal of neuroscience 15, 1907-1917.

Elder, A., Gelein, R., Silva, V., Feikert, T., Opanashuk, L., Carter, J., Potter, R., Maynard, A., Ito, Y., Finkelstein, J., Oberdorster, G., 2006. Translocation of inhaled ultrafine manganese oxide particles to the central nervous system. Environmental health perspectives 114, 1172-1178. 
Evans, J., Hastings, L., 1992. Accumulation of Cd(II) in the CNS depending on the route of administration: intraperitoneal, intratracheal, or intranasal. Fundamental and applied toxicology : official journal of the Society of Toxicology 19, 275-278.

Gagnaire, F., Boucard, S., 2014. Olfactory mucosal necrosis in rats following acute intraperitoneal administration of 1,2-diethylbenzene, 1,2-diacetylbenzene and 2,5-hexanedione. Neurotoxicology 41, 9-19.

Garcia, G.J., Kimbell, J.S., 2009. Deposition of inhaled nanoparticles in the rat nasal passages: dose to the olfactory region. Inhalation toxicology 21, 1165-1175.

Gerde, P., Cheng, Y.S., Medinsky, M.A., 1991. In vivo deposition of ultrafine aerosols in the nasal airway of the rat. Fundamental and applied toxicology : official journal of the Society of Toxicology $16,330-336$

Gianutsos, G., Morrow, G.R., Morris, J.B., 1997. Accumulation of manganese in rat brain following intranasal administration. Fundamental and applied toxicology : official journal of the Society of Toxicology 37, 102-105.

Gomez, M., Sanchez, D.J., Llobet, J.M., Corbella, J., Domingo, J.L., 1997. The effect of age on aluminum retention in rats. Toxicology 116, 1-8.

Hansen, L.F., Hammer, M., Petersen, S.H., Nielsen, G.D., 1994. Effects of intranasal ZnSO4 irrigation on olfactory and trigeminal cues. Physiology \& behavior 55, 699-704.

Henriksson, J., Tallkvist, J., Tjalve, H., 1997. Uptake of nickel into the brain via olfactory neurons in rats. Toxicol. Lett. 91, 153-162.

Ibanez, C., Suhard, D., Tessier, C., Delissen, O., Lestaevel, P., Dublineau, I., Gourmelon, P., 2014. Intranasal exposure to uranium results in direct transfer to the brain along olfactory nerve bundles. Neuropathology and applied neurobiology 40, 477-488.

Kao, Y.Y., Cheng, T.J., Yang, D.M., Wang, C.T., Chiung, Y.M., Liu, P.S., 2012. Demonstration of an olfactory bulb-brain translocation pathway for $\mathrm{ZnO}$ nanoparticles in rodent cells in vitro and in vivo. Journal of molecular neuroscience : MN 48, 464-471.

Keyhani, K., Scherer, P.W., Mozell, M.M., 1997. A numerical model of nasal odorant transport for the analysis of human olfaction. J Theor Biol 186, 279-301.

Kimbell, J.S., Godo, M.N., Gross, E.A., Joyner, D.R., Richardson, R.B., Morgan, K.T., 1997. Computer simulation of inspiratory airflow in all regions of the F344 rat nasal passages. Toxicology and applied pharmacology 145, 388-398.

Kreyling, W.G., 2016. Discovery of unique and ENM- specific pathophysiologic pathways: Comparison of the translocation of inhaled iridium nanoparticles from nasal epithelium versus alveolar epithelium towards the brain of rats. Toxicology and applied pharmacology 299, 41-46.

Kwon, J.T., Seo, G.B., Jo, Lee, M., Kim, H.M., Shim, I., Lee, B.W., Yoon, B.I., Kim, P., Choi, K., 2013. Aluminum Nanoparticles Induce ERK and p38MAPK Activation in Rat Brain. Toxicological research 29, 181-185.

Oberdorster, G., Sharp, Z., Atudorei, V., Elder, A., Gelein, R., Kreyling, W., Cox, C., 2004. Translocation of inhaled ultrafine particles to the brain. Inhalation toxicology 16, 437-445. 
Perge, J.A., Niven, J.E., Mugnaini, E., Balasubramanian, V., Sterling, P., 2012. Why do axons differ in caliber? J Neurosci 32, 626-638.

Perl, D.P., Good, P.F., 1991. Aluminum, Alzheimer's disease, and the olfactory system. Annals of the New York Academy of Sciences 640, 8-13.

Prabhakar, P.V., Reddy, U.A., Singh, S.P., Balasubramanyam, A., Rahman, M.F., Indu Kumari, S., Agawane, S.B., Murty, U.S., Grover, P., Mahboob, M., 2012. Oxidative stress induced by aluminum oxide nanomaterials after acute oral treatment in Wistar rats. Journal of applied toxicology : JAT 32, 436-445.

Rollin, H.B., Theodorou, P., Cantrell, A.C., 1996. Biological indicators of exposure to total and respirable aluminium dust fractions in a primary aluminium smelter. Occupational and environmental medicine 53, 417-421.

Rollin, H.B., Theodorou, P., Nogueir, C.M., Levin, J., 2001. Aluminium uptake and excretion in potroom workers of a new primary aluminium smelter during the construction stage. J Environ Monit $3,560-564$.

Sanchez-Iglesias, S., Soto-Otero, R., Iglesias-Gonzalez, J., Barciela-Alonso, M.C., Bermejo-Barrera, P., Mendez-Alvarez, E., 2007. Analysis of brain regional distribution of aluminium in rats via oral and intraperitoneal administration. Journal of trace elements in medicine and biology : organ of the Society for Minerals and Trace Elements (GMS) 21 Suppl 1, 31-34.

Shipley, M.T., 1985. Transport of molecules from nose to brain: transneuronal anterograde and retrograde labeling in the rat olfactory system by wheat germ agglutinin-horseradish peroxidase applied to the nasal epithelium. Brain research bulletin 15, 129-142.

Southam, D.S., Dolovich, M., O'Byrne, P.M., Inman, M.D., 2002. Distribution of intranasal instillations in mice: effects of volume, time, body position, and anesthesia. American journal of physiology. Lung cellular and molecular physiology 282, L833-839.

Sun, T.J., Miller, M.L., Hastings, L., 1996. Effects of inhalation of cadmium on the rat olfactory system: behavior and morphology. Neurotoxicology and teratology 18, 89-98.

Sunderman, F.W., Jr., 2001. Nasal toxicity, carcinogenicity, and olfactory uptake of metals. Ann Clin Lab Sci 31, 3-24.

Tin Tin Win, Shwe., Mitsushima, D., Yamamoto, S., Fukushima, A., Funabashi, T., Kobayashi, T., Fujimaki, H., 2008. Changes in neurotransmitter levels and proinflammatory cytokine mRNA expressions in the mice olfactory bulb following nanoparticle exposure. Toxicology and applied pharmacology 226, 192-198.

Tjalve, H., Henriksson, J., Tallkvist, J., Larsson, B.S., Lindquist, N.G., 1996. Uptake of manganese and cadmium from the nasal mucosa into the central nervous system via olfactory pathways in rats. Pharmacology \& toxicology 79, 347-356.

Tjalve, H., Henriksson, J., 1999. Uptake of metals in the brain via olfactory pathways. Neurotoxicology 20, 181-195.

van Ginkel, M.F., van der Voet, G.B., de Wolff, F.A., 1990. Improved method of analysis for aluminum in brain tissue. Clinical chemistry 36, 658-661. 
Wang, J., Liu, Y., Jiao, F., Lao, F., Li, W., Gu, Y., Li, Y., Ge, C., Zhou, G., Li, B., Zhao, Y., Chai, Z., Chen, C., 2008. Time-dependent translocation and potential impairment on central nervous system by intranasally instilled TiO(2) nanoparticles. Toxicology 254, 82-90.

Wang, B., Feng, W.Y., Wang, M., Shi, J.W., Zhang, F., Ouyang, H., Zhao, Y.L., Chai, Z.F., Huang, Y.Y., Xie, Y.N., Wang, H.F., Wang, J., 2007. Transport of intranasally instilled fine $\mathrm{Fe}_{2} \mathrm{O}_{3}$ particles into the brain: micro-distribution, chemical states, and histopathological observation. Biological trace element research 118, 233-243.

Yokel, R.A., McNamara, P.J., 2001. Aluminium toxicokinetics: an updated minireview. Pharmacology \& toxicology 88, 159-167.

Young, J.T., 1981. Histopathologic examination of the rat nasal cavity. Fundamental and applied toxicology : official journal of the Society of Toxicology 1, 309-312.

Zatta, P., Favarato, M., Nicolini, M., 1993. Deposition of aluminum in brain tissues of rats exposed to inhalation of aluminium acetylacetonate. Neuroreport 4, 1119-1122.

Zhang, Q.L., Li, M.Q., Ji, J.W., Gao, F.P., Bai, R., Chen, C.Y., Wang, Z.W., Zhang, C., Niu, Q., 2011. In vivo toxicity of nano-alumina on mice neurobehavioral profiles and the potential mechanisms. International journal of immunopathology and pharmacology 24, 23S-29S.

Zhang, X., Xu, Y., Zhou, L., Zhang, C., Meng, Q., Wu, S., Wang, S., Ding, Z., Chen, X., Li, X., Chen, R., 2015. Sex-Dependent Depression-Like Behavior Induced by Respiratory Administration of Aluminum Oxide Nanoparticles. International journal of environmental research and public health $12,15692-$ 15705.

Figure Legends

Fig.1. Rat nose, midsagittal section. Vertical lines indicate the anatomical levels examined in this study

Fig.2. Rat olfactory mucosa (sections II, III and IV of the nasal cavities) after instillation of $30 \mu \mathrm{L}$ of $\mathrm{ZnSO}_{4} 5 \%$ in the left nostril. HES-stained sections, S: septum, a: olfactory epithelium from the contralateral side, b: olfactory epithelium from the ipsilateral side (instilled side). Necrosis of the olfactory epithelium is evident in the ipsilateral side at the three anatomical levels examined. The nasal lumen is filled with inflammatory cells (level IV ipsi). The olfactory epithelium from the contralateral side is intact at the three anatomical levels examined

Fig.3. Tissue manganese levels $(\mu \mathrm{g} / \mathrm{g})$ in the contralateral (Contra OB) and ipsilateral olfactory bulbs (Ipsi OB) from rats instilled with single $(10 \mu \mathrm{g}$ and $25 \mu \mathrm{g}$ of $\mathrm{Mn} / 30 \mu \mathrm{L})$ and repeated (10 $\mu \mathrm{g}$ of $\mathrm{Mn} /$ $30 \mu \mathrm{L}$ for 10 days) doses of manganese chloride via the left nostril. Controls were exposed to saline in the same conditions. Animals were sacrificed 24 hours after the last dose. Each value represents the mean \pm SEM. The number of animals in each group was $n=8$. ${ }^{* * *} p<0.001$ (Student's $t$ test, ipsi exposed vs. ipsi controls); \#\#\# $p<0.001$ (Paired Student's t test, ipsi exposed vs. contra exposed), $\star \star \star \mathrm{p}<0.001$ (Student's $\mathrm{t}$ test, contra exposed vs. contra controls)

Fig.4A. Aluminum levels $(\mu \mathrm{g} / \mathrm{g})$ in the olfactory bulbs and cerebellum from rats treated intraperitoneally with aluminum chloride for 7 days $\left(10 \mathrm{mg} \mathrm{Al} \mathrm{l}^{3+} / \mathrm{kg} /\right.$ day). Control animals received an intraperitoneal injection of saline. OB values represent the mean \pm SEM from 6 assays. For each 
assay, $8 \mathrm{OB}$ ( 4 rats) were pooled; the cerebellum values correspond to the mean \pm SEM from 24 cerebellum. Student's test, $* * * \mathrm{p}<0.001$ (treated versus controls).

4B. Plasma aluminum concentrations ( $\mu \mathrm{g} / \mathrm{L}$ ) for 6 controls (white bar) and 8 treated rats (gray bar). Student's test, ${ }^{* * *} \mathrm{p}<0.001$ (treated versus controls)

Fig.5. High-magnification photomicrograph of the ethmoturbinate at level IV of the olfactory mucosa on the contralateral and ipsilateral sides to the instilled nostril after repeated instillations of $\mathrm{AlCl}_{3}(10$ days). Sections were stained with HES. No lesions were observed in the olfactory epithelium from either side of the nasal cavity

Fig.6. Aluminum levels ( $\mu \mathrm{g} / \mathrm{g}$ ) measured in the contralateral (Contra) and ipsilateral (Ipsi) olfactory bulbs from rats exposed to repeated intranasal instillations of aluminum chloride for 10 days (10 $\mu \mathrm{g}$ $\mathrm{Al} / 30 \mu \mathrm{L} /$ day). The values represent the mean \pm SEM of assays performed on "contra" (white bars) and "ipsi" (gray bars) bulbs from control and treated rats. Each assay was performed by pooling 8 OBs from 8 rats. ${ }^{* * *} p<0.001$, ipsi exposed OB vs. ipsi control OB (Student's t test); $\# p<0.05$, ipsi exposed vs. contra exposed (Paired Student's t test); ${ }^{*} p<0.05$, contra exposed OB vs. contra control $\mathrm{OB}$ (Student's t test)

Fig.7A. Section IV of the rat nasal cavity after repeated instillations of $\mathrm{AlF}_{3}$ (10 days). The ethmoturbinates are numbered from 1 to 6 . Original magnification $2 \mathrm{x}$. In the exposed nasal cavity (ipsilateral side), limited olfactory epithelial necrosis is observed in the internal fold of ethmoturbinates 1 and 2. The box indicates the region of the mucosa shown in Fig. 7B. (B) Higher magnification showing ethmoturbinates 1 and 2 . The neuroepithelium of the external folds was unaltered (arrows). The internal folds exhibited complete loss of sensory cells (arrow heads). The nasal lumen of the internal fold was filled with inflammatory and dead cells (asterisk)

Fig.8. Aluminum levels ( $\mu \mathrm{g} / \mathrm{g}$ ) measured in the contralateral (Contra) and ipsilateral (Ipsi) olfactory bulbs from rats exposed to repeated intranasal instillations of aluminum fluoride over 10 days (10 $\mu \mathrm{g}$ $\mathrm{Al} / 30 \mu \mathrm{L} /$ day). Values represent the mean \pm SEM of 9 assays on "contra" (white bars) and "ipsi" (gray bars) olfactory bulbs from control and treated rats. Each assay was performed by pooling 8 OBs from 8 rats. ${ }^{*} p<0.05$, Ipsi exposed OB versus Ipsi control OB (Student's t test)

Table 1. Chemical and physical particle characterization. PDI: Polydispersity indices 


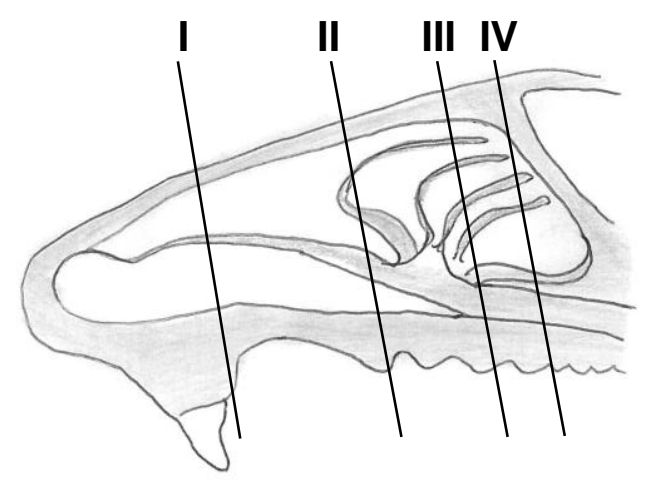

Fig. 1. Rat nose, midsagittal section. Vertical lines indicate the anatomical levels examined in this study. 


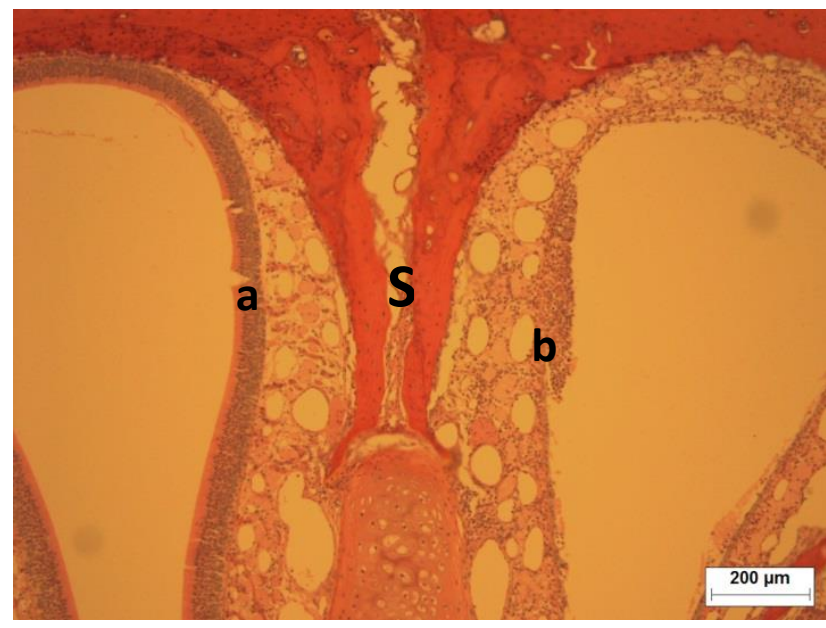

II

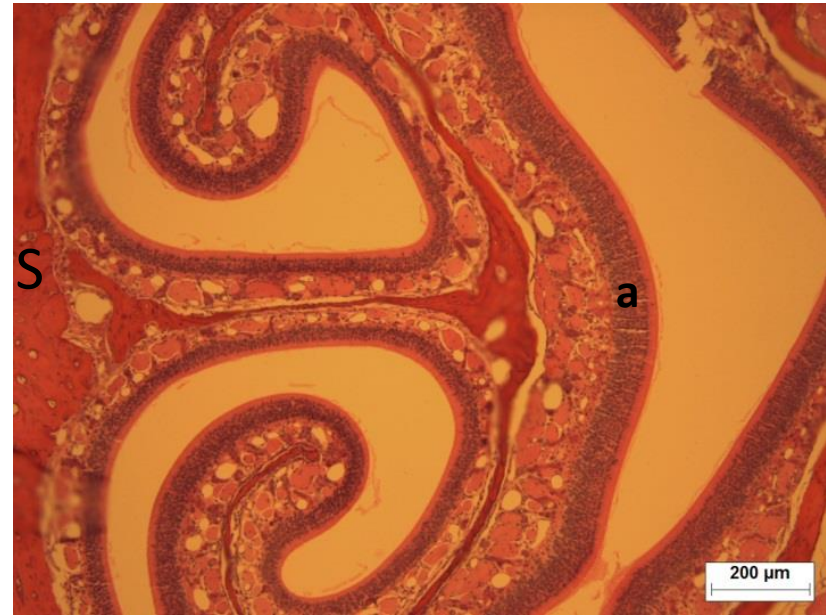

IV contra

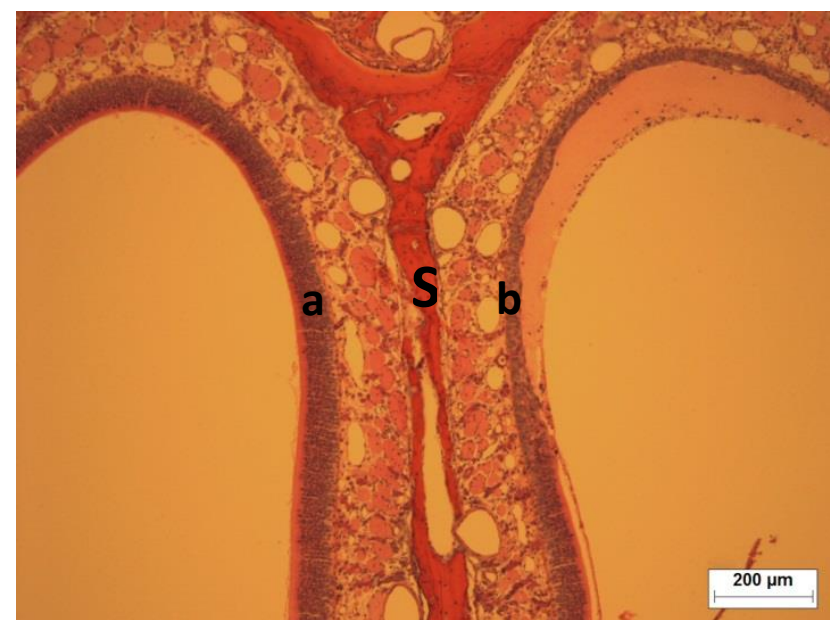

III

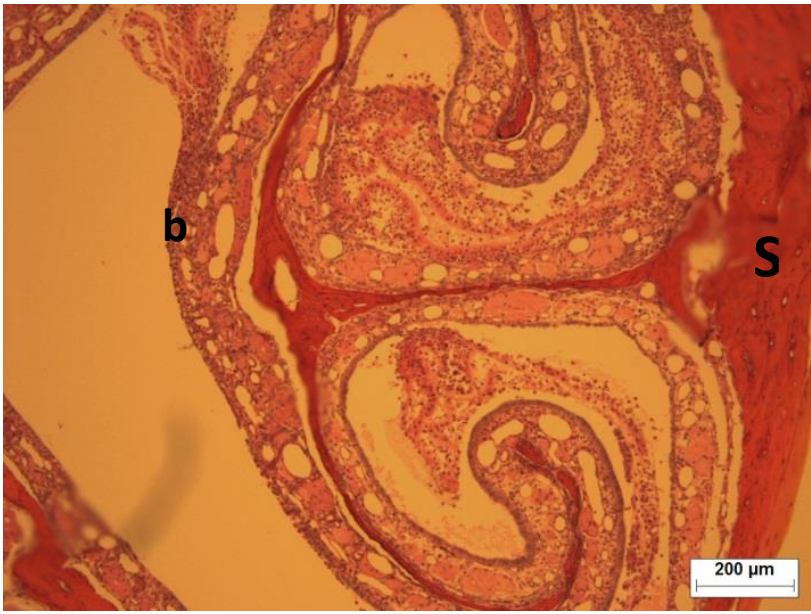

IV ipsi

Fig.2. Rat olfactory mucosa (sections II, III and IV of the nasal cavities) after instillation of $30 \mu \mathrm{L}$ of $\mathrm{ZnSO}_{4}$ $5 \%$ in the left nostril. HES-stained sections, S: septum, a: olfactory epithelium from the contralateral side, b: olfactory epithelium from the ipsilateral side (instilled side). Necrosis of the olfactory epithelium is evident in the ipsilateral side at the three anatomical levels examined. The nasal lumen is filled with inflammatory cells (level IV ipsi). The olfactory epithelium from the contralateral side is intact at the three anatomical levels examined. 


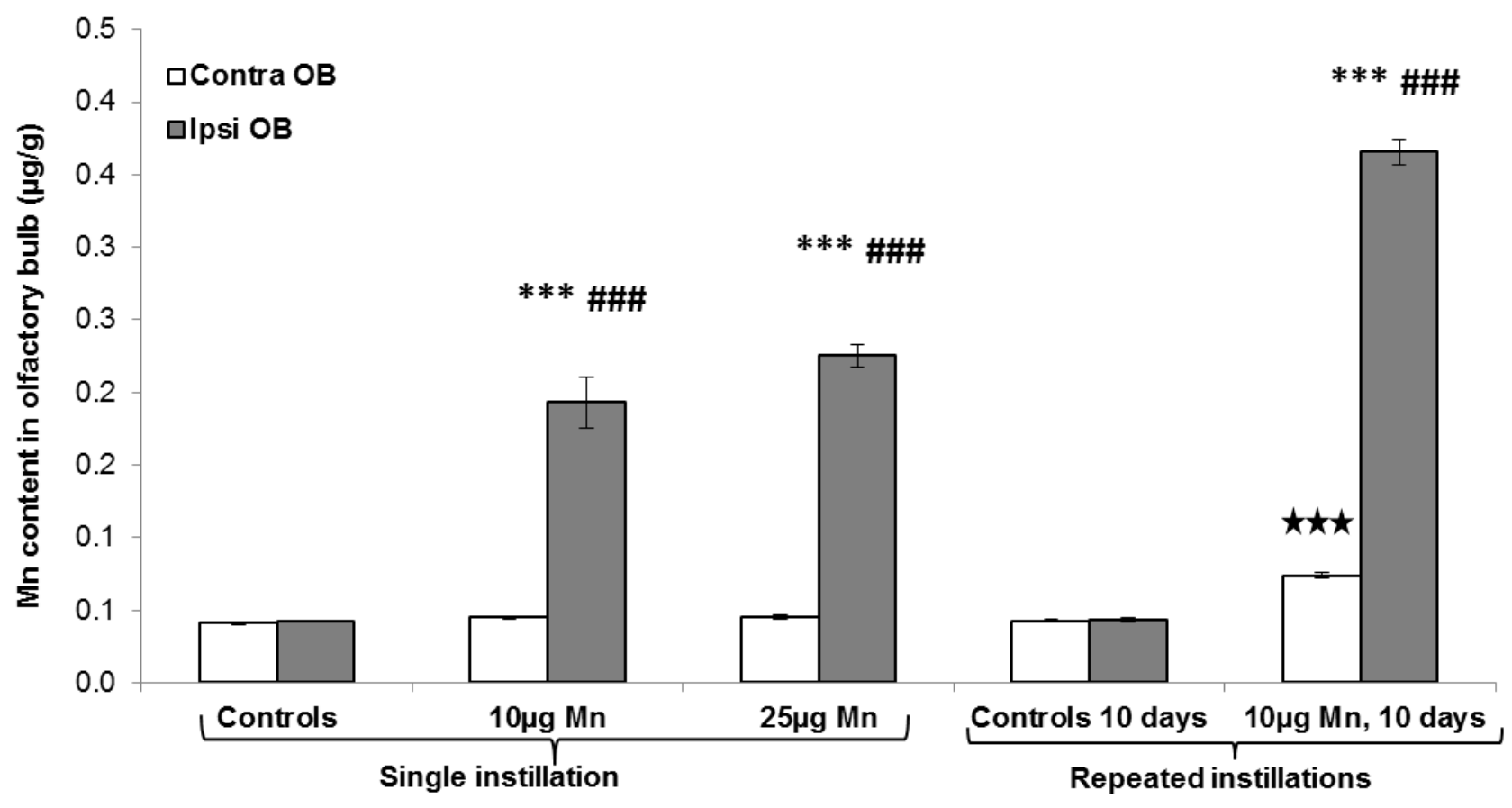

Fig.3. Tissue manganese levels $(\mu \mathrm{g} / \mathrm{g})$ in the contralateral (Contra $\mathrm{OB}$ ) and ipsilateral olfactory bulbs (Ipsi OB) from rats instilled with single (10 $\mu \mathrm{g}$ and $25 \mu \mathrm{g}$ of $\mathrm{Mn} / 30 \mu \mathrm{L})$ and repeated (10 $\mu \mathrm{g}$ of $\mathrm{Mn} /$ $30 \mu \mathrm{l}$ for 10 days) doses of manganese chloride via the left nostril. Controls were exposed to saline in the same conditions. Animals were sacrificed 24 hours after the last dose. Each value represents the mean \pm SEM. The number of animals in each group was $n=8 .{ }^{* * *} p<0.001$ (Student's t test, ipsi exposed vs. ipsi controls); \# \# \# $<0.001$ (Paired Student's t test, ipsi exposed vs. contra exposed), $\star \star \star p<0.001$ (Student's $t$ test, contra exposed vs. contra controls). 

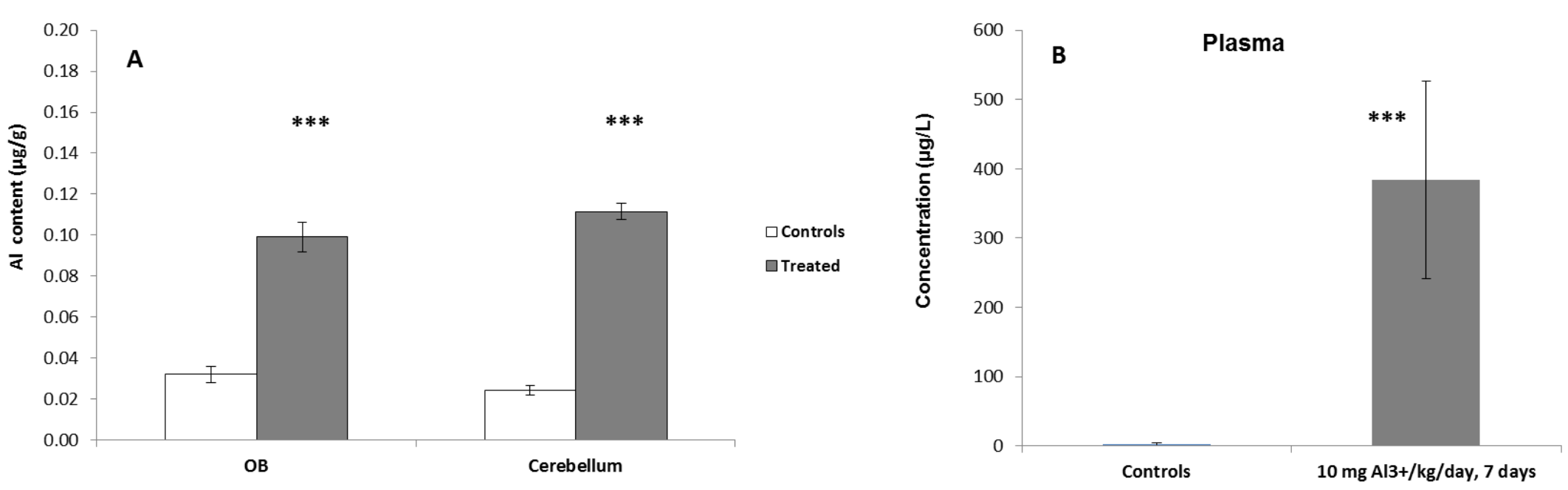

Fig.4A. Aluminum levels $(\mu \mathrm{g} / \mathrm{g})$ in the olfactory bulbs and cerebellum from rats treated intraperitoneally with aluminum chloride for 7 days $\left(10 \mathrm{mg} \mathrm{Al}^{3}\right.$ $+/ \mathrm{kg} /$ day). Control animals received an intraperitoneal injection of saline. OB values represent the mean \pm SEM from 6 assays. For each assay, 8 OB (4 rats) were pooled; the cerebellum values correspond to the mean \pm SEM from 24 cerebellum. Student's test, ${ }^{* * *} \mathrm{p}<0.001$ (treated versus controls).

4B. Plasma aluminum concentrations ( $\mu \mathrm{g} / \mathrm{L}$ ) for 6 controls (white bar) and 8 treated rats (gray bar). Student's test, $* * * p<0.001$ (treated versus controls). 

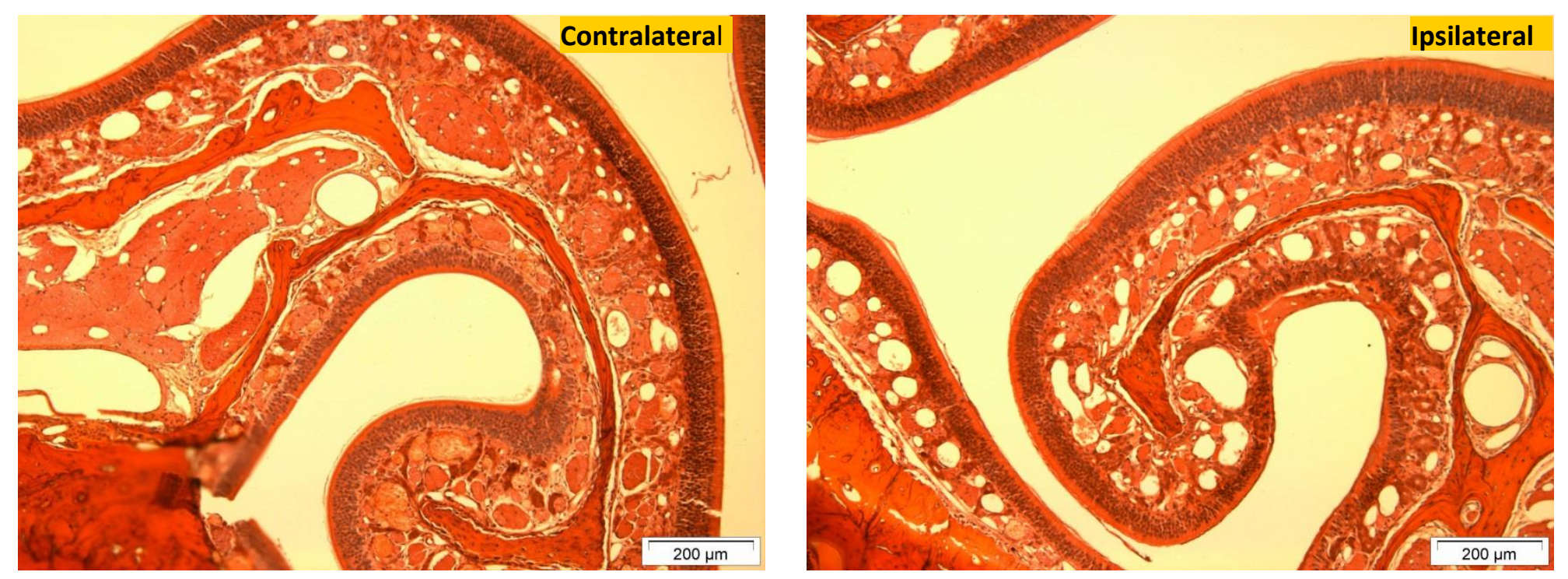

Fig.5. High-magnification photomicrograph of the ethmoturbinate at level IV of the olfactory mucosa on the contralateral and ipsilateral sides to the instilled nostril after repeated instillations of $\mathrm{AlCl}_{3}(10$ days). Sections were stained with HES. No lesions were observed in the olfactory epithelium from either side of the nasal cavity. 


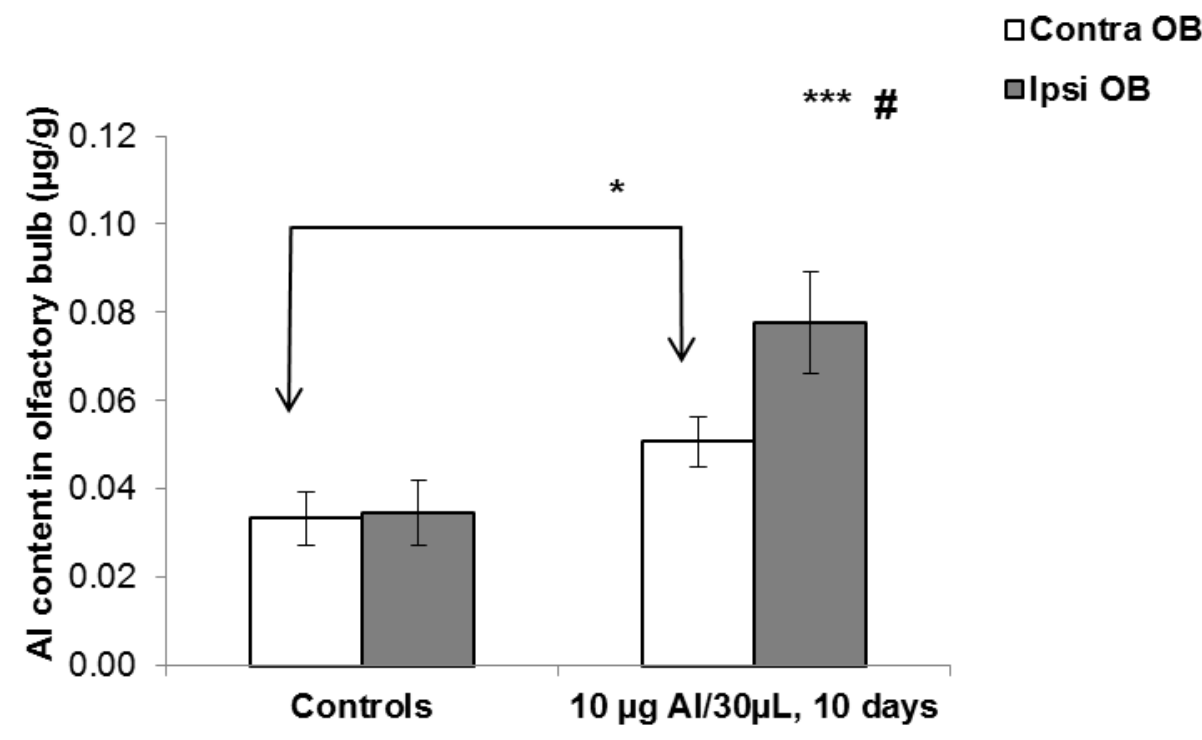

Fig.6: Aluminum levels ( $\mu \mathrm{g} / \mathrm{g}$ ) measured in the contralateral (Contra) and ipsilateral (Ipsi) olfactory bulbs from rats exposed to repeated intranasal instillations of aluminum chloride for 10 days $(10 \mu \mathrm{g}$ $\mathrm{Al} / 30 \mu \mathrm{l} / \mathrm{day}$ ). The values represent the mean \pm SEM of assays performed on "contra" (white bars) and "ipsi" (gray bars) bulbs from control and treated rats. Each assay was performed by pooling 8 OBs from 8 rats. ${ }^{* * *} p<0.001$, ipsi exposed OB vs. ipsi control OB (Student's t test); $\# p<0.05$, ipsi exposed vs. contra exposed (Paired Student's $t$ test); ${ }^{*} p<0.05$, contra exposed OB vs. contra control OB (Student's t test). 


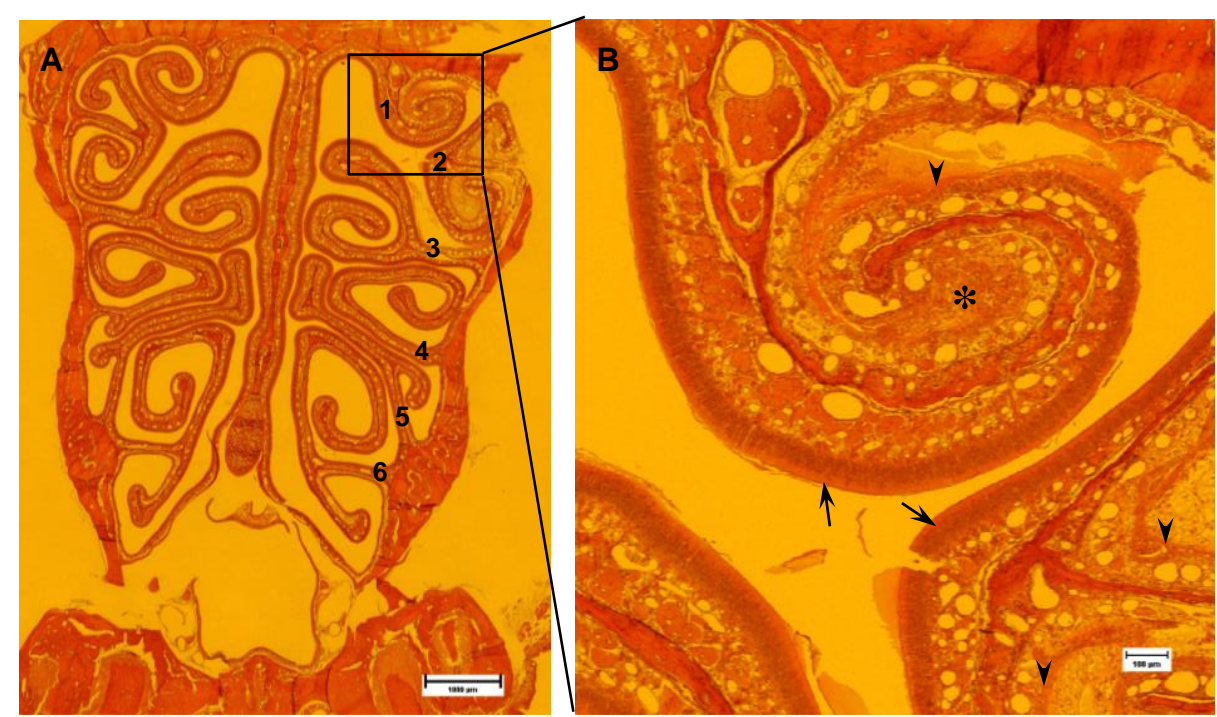

Fig. 7A Section IV of the rat nasal cavity after repeated instillations of AlF $_{3}$ (10 days). The ethmoturbinates are numbered from 1 to 6 . Original magnification $2 \mathrm{x}$. In the exposed nasal cavity (ipsilateral side), limited olfactory epithelial necrosis is observed in the internal fold of ethmoturbinates 1 and 2. The box indicates the region of the mucosa shown in Fig. 7B. (B) Higher magnification showing ethmoturbinates 1 and 2 . The neuroepithelium of the external folds was unaltered (arrows). The internal folds exhibited complete loss of sensory cells (arrow heads). The nasal lumen of the internal fold was filled with inflammatory and dead cells (asterisk). 


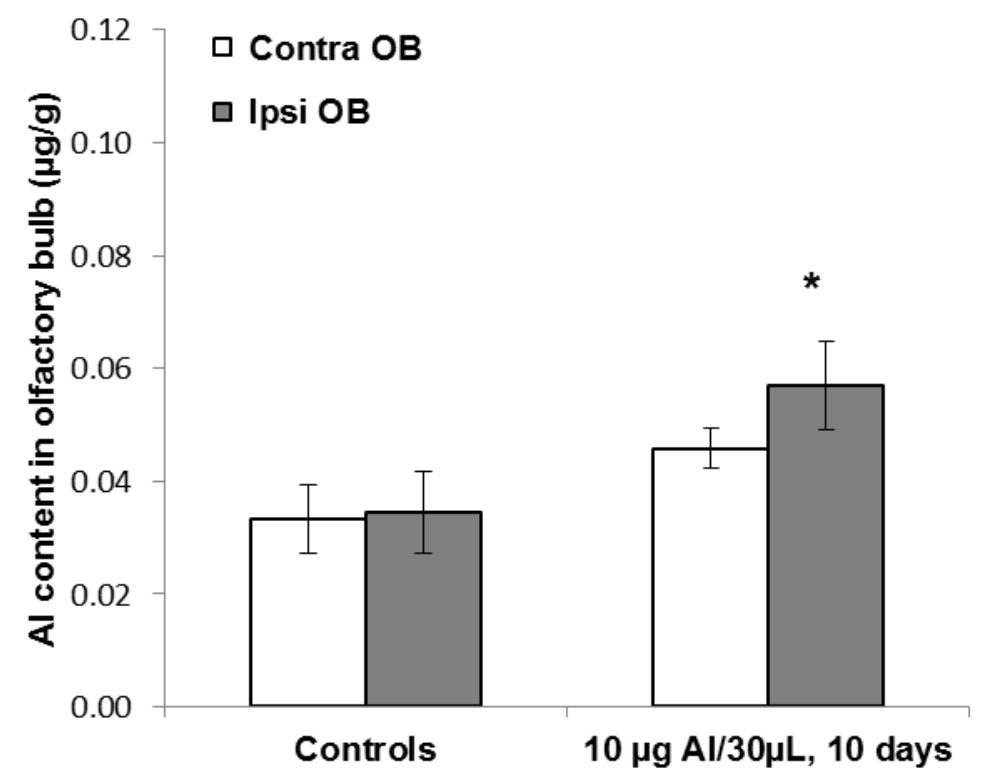

Fig.8: Aluminum levels $(\mu \mathrm{g} / \mathrm{g}$ ) measured in the contralateral (Contra) and ipsilateral (Ipsi) olfactory bulbs from rats exposed to repeated intranasal instillations of aluminum fluoride over 10 days $(10 \mu \mathrm{g}$ $\mathrm{Al} / 30 \mu \mathrm{L} / \mathrm{day}$ ). Values represent the mean \pm SEM of 9 assays on "contra" (white bars) and "ipsi" (gray bars) olfactory bulbs from control and treated rats. Each assay was performed by pooling 8 OBs from 8 rats. ${ }^{*} p<0.05$, Ipsi exposed OB versus Ipsi control OB (Student's t test) 